Revista de la red interuniversitaria de estudios sobre las literaturas rioplatenses contemporáneas en Francia

$13 \mid 2015$

Nuevas experiencias editoriales y literaturas

contemporáneas

\title{
Una experiencia lograda
}

\section{Gonzalo Carranza}

\section{OpenEdition}

\section{Journals}

Edición electrónica

URL: http://journals.openedition.org/lirico/2042

DOI: $10.4000 /$ lirico.2042

ISSN: 2262-8339

Editor

Réseau interuniversitaire d'étude des littératures contemporaines du Río de la Plata

Referencia electrónica

Gonzalo Carranza, « Una experiencia lograda », Cuadernos LIRICO [En línea], 13 | 2015, Publicado el 15 diciembre 2015, consultado el 24 septiembre 2020. URL : http://journals.openedition.org/lirico/2042 ; DOI : https://doi.org/10.4000/lirico.2042

Este documento fue generado automáticamente el 24 septiembre 2020

\section{(c) (i) () $\Theta$}

Cuadernos LIRICO está distribuido bajo una Licencia Creative Commons Atribución-NoComercialSinDerivar 4.0 Internacional 


\title{
Una experiencia lograda
}

\author{
Gonzalo Carranza
}

\section{REFERENCIA}

Damiani, Marcelo. La distracción. Buenos Aires : Simurg, 2014, 147 p.

1 A William Burroughs le gustaba decir que la crítica llama experimental a una novela cuando el experimento sale mal. Afortunadamente la narrativa de Marcelo Damiani demuestra que la innovación a veces también puede construir tramas interesantes y personajes bien definidos. La poesía, la crónica y el ensayo apuntan, cada uno de ellos, claro está, en otras direcciones, pero, a pesar de las cantidades siderales de agua que ha pasado bajo el puente desde que este género ocupa el centro de la narrativa, las peripecias de la trama y el retrato de los personajes continúan siendo los primeros elementos que el lector suele recordar cuando cierra las tapas de un libro que se ha propuesto asimismo como una novela. $¿ \mathrm{Y}$ en qué radica entonces el carácter experimental de nuestro autor? ¿Qué lo diferencia de otros novelistas? Tal vez una lectura de los usos que Marcelo Damiani hace de las convenciones de determinados géneros narrativos pueda echar luz sobre estas preguntas. En el caso concreto de La distracción, este trabajo también, incluso, quizás nos ayude a entender los mecanismos internos que permiten la aparición del humor y el despliegue del suspenso que son otras de las marcas características de esta novela.

2 La Distracción puede incluirse sin grandes dificultades en la larga lista que conforman las novelas de campus, como suele denominarse a los textos narrativos que transcurren en ese mundo aparte que, al menos en la tradición anglo-norteamericana, conforman las universidades y algunas casas de estudios que nosotros identificaríamos con lo que llamamos la escuela secundaria. A esa familia pertenecen entre otros textos Pnin (1957) de Vladimir Nabokov, Todas las Almas (1989) de Javier Marías, y la asombrosa Cuando Alicia se subió arriba de la mesa (1997) de Jonathan Lethem. La trama de esos textos se circunscribe a los límites físicos de la institución educativa y los personajes muchas veces parecen ignorar que afuera hay otro mundo, como si se hubieran propuesto 
imitar a los habitantes de la vieja caverna de Platón. La novela de campus reconoce un antecedente en aquella tradicional novela inglesa en la que los personajes se retiran a pasar una breve temporada en una casa de campo, como suele ocurrir en algunos textos de Elizabeth Bowen o de L. P. Hartley, pero aquí es el saber (y no las jerarquías de clase) el elemento que articula las diferencias entre los personajes. La distracción, sin embargo, se aparta en este punto del camino más transitado por el género para ubicarse más cerca de Lethem que de Marías. Recordemos que mientras el narrador de Todas las almas es un profesor al que podríamos sin dificultad adscribir a la tradición clásica, el protagonista de Cuando Alicia se subió..., en cambio, es un sociólogo funcionalista que se siente depositario de un saber reciente, endeble e ineficaz. No se trata de todos modos de un giro a la picaresca. Los personajes de La distracción no son farsantes que hacen gala de contar con algo que, en realidad, no les pertenece o que utilizan sin comprenderlo. Todo lo contrario. La novela, en definitiva, pone en cuestión el saber que debería servirle de fundamento. El procedimiento empuja el texto a la paradoja. $L a$ distracción, desde este punto de vista, parece comportarse como una novela de horror que descree de las manifestaciones del mundo sobrenatural o un policial que duda acerca de las capacidades del detective para reconstruir el entramado del crimen que él mismo se ha propuesto investigar.

3 Tal vez tendríamos que haberlo dicho antes, pero The Banff Centre for The Arts, la institución donde transcurre la trama de Damiani, está ubicada en el extremo oeste de Canadá. Uno de los personajes de la novela sostiene que sus moradores temporarios son aún más extraños que la fauna ártica que los rodea. Y también son absurdas las prácticas y evaluaciones que les asigna la institución. No debe llamarnos la atención entonces que en semejante contexto Reynaldo Gómez y Nicolás Campriglia -los críticos de cine que componen la entidad llamada Reyni para elaborar y firmar sus escritoshayan renunciado a cualquier reflexión teórica sobre el cine previo a su propia experiencia. Pero sería injusto sostener que estos personajes sólo cuentan con su sensibilidad a la hora de juzgar un film. Reyni tiene un método, como también lo tiene Hermeto, el alter ego de nuestro crítico bicéfalo que, como no podía ser de otro modo si tenemos en cuenta su nombre, ha decidido inclinarse por la reflexión filosófica. Y el método es eficaz. Se trata ni más ni menos que de poner en acto la propia lengua. No bien comenzamos a familiarizarnos con los personajes de la novela, comprendemos que tanto su pensamiento como sus acciones avanzan a partir de liberar a las palabras del ancla que les ha asignado la comunicación cotidiana. El discurso se desliza entones con la más absoluta autonomía y es esa deriva la que termina articulando nuevos sentidos y nuevas significaciones. Las palabras se mueven con la misma velocidad de un fotograma y el lector no tiene más remedio que correr al frenético ritmo que le proponen esta sucesión de encadenamientos. Así, por ejemplo, a poco de comenzar la lectura encontramos que los problemas de dicción de un compositor y violinista belga que integra el grupo de los personajes eran tan graves que se convertían en una contradicción y finalmente en una adicción que lo separa de sus compañeros. Pero no nos apuremos a equiparar este recurso, por llamarlo de alguna manera, con el humor y los juegos de palabras. El procedimiento llega mucho más lejos. Un recuerdo infantil de Reynaldo Gómez, que se utiliza para presentar al personaje, puede servirnos para entender el uso que hace Damiani de él. El narrador nos cuenta cómo en la antigua percepción del protagonista las estrellas de Hollywood se confunden con las del firmamento. La escena tiene lugar en una solitaria excursión a un autocine en una noche de verano y es una de las más bellas del texto. 
[Rey] se escabullía los sábados a la noche con la excusa del encuentro entre amigos, cuando en realidad iba al autocine con la esperanza de encontrar a escondidas por un agujero en el alambrado o gracias a algún descuido de los vigilantes. Pero nunca tenía suerte. Así llegó a conocer muy bien todos los alrededores del lugar, y una noche descubrió un árbol desde el que podía ver toda la pantalla gigante. Era cierto que no podía escuchar nada, pero le pareció divertido tratar de leer los labios a los actores, y además, muchas veces los gestos o las miradas decían más que todos los diálogos del mundo. Una de las mejores imágenes que recordaba, esa que le permitió descubrir el secreto de las estrellas, era la de una mujer de belleza inolvidable; nunca supo su nombre, o quizá lo olvidó a propósito para guardar mejor su recuerdo. Ella acababa de cometer un acto atroz, vengativo, imperdonable, y sin embargo, uno no podía dejar de disfrutar de sus rasgos perfectos y de su perfecto pelo negro. La imagen que nunca podría olvidar era la de ella mirando al frente, a su amante, a la cámara : A él ; sus ojos verdes relampagueando en medio de la noche mientras el fondo oscuro de la pantalla se fundía con el cielo estrellado. Entonces descubrió el secreto ; entonces comprendió por qué a algunas actrices les decían estrellas. ${ }^{1}$

La distracción, entonces, vuelve a plantearnos que la experimentación no debe ser entendida solamente como una cuestión intelectual. El matiz de artificialidad que tiene el término pierde aquí su sentido para mostrarnos que éste puede ser también una de las formas de narrar tan solo la experiencia.

5 El pensamiento de Reyni no reconoce otra lógica, y tampoco, por supuesto, su forma de ver el cine. Aquí la novela reconoce una deuda con la prosa pirotécnica de Guillermo Cabrera Infante, y lo hace convirtiéndolo en una suerte de personaje que, si bien está ausente del hilo principal, aparece como una especie de mentor, tanto de los personajes como del marco de la novela. Claro que no se trata sólo de una cuestión de estilo. También Cabrera Infante fue crítico de cine y también él encontró en la deriva constante de las imágenes una forma de articular sus historias.

6 La apuesta que supone reemplazar la reflexión teórica por la poesía -porque de eso se trata en última instancia el método de Reyni- no implica vaciar el texto de otras referencias culturales. La apelación a Cabrera trae consigo la sombra de Orson Welles y numerosas menciones al cine de Hollywood. También aparecen en el texto Heidegger y el demonio que en vano pretendía engañar a Descartes. ${ }^{2}$

7 La distracción, así, no vacila en mezclar, siempre con la lógica que hemos visto, lo popular con la llamada alta cultura, deteniéndose también en la tradición clásica. La funcionalización de Cabrera Infante le sirve al narrador para plantear una suerte de versión libre de Anfitrión, la comedia de Plauto que tiene como eje central el tema del doble y la sustitución de lo auténtico por la copia. La novela, no obstante, y aquí nos estamos adentrando en el argumento, no parece hacerse muchas ilusiones en la especularidad y las relaciones complementarias. Damiani pondrá un tercer elemento entre un crítico y otro, y ese tercer elemento no podía ser más que una mujer. Es como si el texto tratara de hacerse eco de la gran pregunta sin respuesta que el mismo Freud confesaba no haber podido responder a pesar de su larga experiencia en el estudio del alma femenina : ¿ Qué quiere la mujer?

8 Pero lo mejor será detenernos acá y comenzar a leer la novela. Quizá no sepamos muy bien qué es una experiencia (literaria, masculina, femenina, vital), pero todos estaremos de acuerdo en que se trata de algo, sin duda, insustituible. 


\section{NOTAS}

1. Damiani, Marcelo. La distracción, Ediciones Simurg, Buenos Aires, 2014, p. 37.

2. En este caso, por una parte, el juego intertextual nos puede llevar al revelador libro Descartes y Plauto : La concepción dramática del sistema cartesiano (1997) de Benjamín García-Hernández, cuya tesis central La distracción potencia de forma natural, especialmente en esa suerte de intermezzo que es "El anfitrión de Caín" (págs. 53-60). Por otro lado, en cuanto a Heidegger, también podemos desembocar en el notable párrafo de Die Grundbegriffe der Metaphysik. Welt - Endlichkeit Einsamkeit (1983) del filósofo alemán que Giorgio Agamben analiza en la sección 14 de L'aperto. L'uomo e l'animale (2002), y que Damiani convierte en un perturbador pre-final homónimo en su novela: “Aburrimiento profundo" (págs. 135-138). Más evidente, pero no por eso menos interesante, es la relación cinematográfico-lúdica del célebre pasaje pedagógico del libro VII de la República de Platón con el capítulo "La caverna de Caín" (págs. 17-23). De la misma manera, otro mito del filósofo griego, esta vez de su Fedro, es reformulado en los dos párrafos finales del curioso episodio titulado "Laos" (págs. 103-105). Todo esto, sumado al epígrafe de Kierkegaard, entre otras cosas, avalaría una lectura en clave filosófica de la novela.

\section{AUTORES \\ GONZALO CARRANZA}

Universidad de Quilmes 